\title{
THE INTERACTIONS BETWEEN WAGES AND PRODUCTIVITY NURTURING THE COUNTRY'S COMPETITIVENESS
}

\author{
Irena Danilevičienė, Boguslavas Gruževskis \\ Labour Market Research Institute, Lithuanian Social Research Centre, A. Goštauto st. 11, LT-01108, Vilnius \\ E-mails: ${ }^{1}$ irena.danileviciene@dsti.lt (corresponding author); ${ }^{2}$ boguslavas.gruzevskis@dsti.lt
}

\begin{abstract}
Nowadays wages are determined according to the results of the work but the increase of salaries leads to the higher productivity and efficient work. Here is a strong interaction between wage and productivity, which leads to the country's competitiveness development. The object of research - the interactions be-tween the wage and productivity. The goal of the article is to assess the influence of wage and productivity on the country's competitiveness. In addition, the following tasks have been implemented: to analyse the theoretical aspects of productivity and wage; to reveal the connection between productivity and wage and to assess the influence of this interaction on the country's competitiveness. In this article, the following methods of analysis are used: an analysis and summarize of the scientific literature, the theoretical and practical statements matching method, analysis of the statistical data, correlation and regression analysis.
\end{abstract}

Keywords: competitiveness, efficiency, labour market, productivity, wage, wage theories.

JEL Classification: E24; J24; J31; O47.

\section{Introduction}

Currently, all EU countries try to implement the objectives of the Europe 2020 strategy, the European Employment Strategy - to achieve the full employment, to improve the quality and labour productivity, to strengthen the unity and social integration (European Commission 2010). In turn, the improvement of labour productivity is closely related to wage and its specification. Wage is one of the key factors that influence person's quality of life, the country's economy and the labour market conditions. Appropriate wage level is determined by focusing on the productivity and employee's motivation to work. Higher productivity leads to higher incomes, which respectively can be used for further wage increases. It follows that between wages and labour productivity is a strong relationship and dependency.

Most Lithuanian (Žaptorius 2005; Vanagas 2009; Šileika et al. 2010) and foreign (Summers 1988; Appleby 2003; Gomez-Salvador et al. 2006; Golnau 2012; Addison et al. 2013; Wratny 2013; Polak 2015) scientists analysed the relationship between wages and labour productivity. Economic theories suggests that wages are determined focusing at work results but higher wages motivate workers to work more productively. Accordingly, productivity growth promotes the fostering of competitiveness of the country and the improvement of country's labour market indicators. It is therefore necessary to assess, whether in Lithuania exist a mutual relationship between productivity and wage, which allows the growth of the country's competitiveness.

The object of research - the interactions between the wage and productivity. The goal of the article is to assess the influence of wage and productivity on country's competitiveness development. To achieve this objective the following tasks have been implemented: to analyse the theoretical aspects of productivity and wage; to reveal the interactions between productivity and wage and to analyse its dynamic; to assess the influence of this interaction on the country's competitiveness. In this article, the following methods of analysis are used: an analysis and summarize of the scientific literature, the theoretical and practical statements matching method, analysis of the statistical data, correlation and regression analysis.

\section{Theoretical aspects of wage and productivity}

Currently to wages, as the main source of people income, are given a special attention of Lithuanian and foreign scientists. Wages influence the living standards of people and its quality, the main components of consumption and economic activity, so the determination of appropriate level of wage is the main economic and legal problem. 
In a narrow sense, the wage is understood as (Žaptorius 2005; Danilevičienè, Kvietkauskienè 2015):

- remuneration, paid to employees for the use of available labour force;

- the amount of money, estimated for a given reporting period;

- wage, determined in accordance with the labour contract/agreement.

Another scientist (Polak 2015) states that the wage is a key human resources management tool, the way to measure personal social value and its benefit that also encourages the growth of economy. It follows that the wage is money received for the execution of certain works and its level is determined by labour supply and demand, the type of work, its quantity and quality (Summers 1988; Wratny 2013).

In terms of wage, it is possible to distinguish the basic objective of wages (Vanagas 2009) - help to implement strategic goals and short-term objectives of organization also growing up the qualification, competencies and dutifulness of employees and motivating them to work productively. It is also necessary to mention that the salary is an economic category, which has a number of basic functions (see Table 1)

Table 1. The main functions of wage (Source: compiled by authors based on Šileika et al. 2010; Danilevičienè, Kvietkauskienè 2015; Polak 2015)

\begin{tabular}{l|l}
\hline \multicolumn{1}{c|}{ Function } & \multicolumn{1}{c}{ Description } \\
\hline Replacement & $\begin{array}{l}\text { The wage ensure the meeting phys- } \\
\text { ical, spiritual and social needs }\end{array}$ \\
\hline $\begin{array}{l}\text { Motivation- } \\
\text { al/economic }\end{array}$ & $\begin{array}{l}\text { The wage stimulates employee sat- } \\
\text { isfaction ongoing work and their } \\
\text { motivation to increase their produc- } \\
\text { tivity }\end{array}$ \\
\hline $\begin{array}{l}\text { Social guarantees } \\
\text { punction/social- } \\
\text { public }\end{array}$ & $\begin{array}{l}\text { Timely and appropriate amount } \\
\text { wage ensures the cost recovery in } \\
\text { the case of simple and complex } \\
\text { work }\end{array}$ \\
\hline Compensational & $\begin{array}{l}\text { This function occurs when an em- } \\
\text { ployee is working in worse condi- } \\
\text { tions than accepted (night shift, } \\
\text { working in difficult conditions), but } \\
\text { for that he receives a relatively } \\
\text { higher wage }\end{array}$ \\
\hline Cumulative & $\begin{array}{l}\text { Wage ensures funding the basic } \\
\text { future needs }\end{array}$ \\
\hline
\end{tabular}

During the search for solutions of the appropriate wage determination, everyone directly facing with the interests of employers and employees, so these questions are dealt with an accordance with the so-called social partnership principles or an opposition to one another. The main tasks of the wage policy are (Appleby 2003):

- to attract and retain the necessary personnel in order to achieve the organization's objectives;

- to encourage employees to work better;

- to follow a logical and coherent, easy to understand and flexible policy.

It follows, that the considerable attention to the wage regulation makes the state when the legislation still consolidating the guaranteed minimum benefits for the employees (Addison et al. 2013).

State-guaranteed benefits do not provide excellent work of employee and the companies in order to improve performance determine more rights and better wage conditions for the employees than those guaranteed by the state. Meanwhile, the company has a possibility to reach the objective of each employer's - to make the best use of each even employee's employment potential and thus increase their productivity. In order to keep good employees in company, it is necessary to pay him a higher wage than could pay other competitors.

In order for an employee to start work better, his wage must be increased by a fixed amount in relation to some of its behaviour education. Only in this case greater productivity will be achieve. In this respect, labour productivity and wage are closely related to each other both in macro and in micro level and their integration creates preconditions for the foster of country's economic competitiveness.

Labour productivity (Vanagas 2009) it is the quantity of products or services that were produced for a certain period, when may have been used some resources. It is the relation between the quantity of products and the amount of used resources while these products were produced. Labour productivity shows the efficiency of the use of labour force when the labour productivity is growing, benefit is creating and the amount of production are increased over the same period (Beržinskiene, Raziulyte 2012; Jorgenson et al. 2014). In macro level (GomezSalvador et al. 2006) it is the interaction between the gross domestic product (GDP) and labour costs. Labour costs are expressed in terms of working hours/number of the employees. The more people are employed, the more efficiently the economy is working.

Labour productivity can be also explained as the efficiency of use of labour force. The growth of labour productivity leads to the increase in production amounts and the society becomes richer. 
Reducing wages the productivity and employees efforts are affected and thus the labour force costs are growing (Summers 1988). The growth of labour productivity also leads to the business subjects' ability to increase the wages, dividends or expand production amount without increasing the prices. High wages limiting staff turnover, so in the company the amount of employees with necessary knowledge and skills and their productivity grows is increased (Golnau 2012). Labour productivity and wage becomes the main economic and legal problem.

The cost of employee is also based on the price of production. If the amount of production will grow slowly than used, the wage will not grow as fast as the productivity. In addition, the wage growth will increase the cost of the employee if the productivity level is stable. The increase in labour productivity leads to the cheaper labour force and the higher number of employees, while growing wages attracts new skilled workers. Increasing productivity allows creating more goods or services with smaller costs but with increasing real wages. If the companies want to expand the production process with the stable labour productivity, it is necessary to adopt new employees with necessary skills.

Using innovations labour productivity may be higher, so if productivity grows faster than the demand it can lead to the rise in unemployment in the short term, although grow in GDP in the long term. Higher productivity allows producing more goods with the same number of employees but increasing employment because the labour cost is decreasing and the creation of new industries are promoted.

While the labour productivity and employment are increasing, the potential GDP is also growing. In order wage level, living standards must increase and the poverty must be reduce. However, wage growth without the growing labour productivity can increase inflation, as well as reducing the country's competitiveness and its attractiveness to foreign investments.

\section{Competitiveness as consequence of the interaction between the wages and productivity}

\subsection{Competitiveness peculiarities}

Scientist (Polak 2015) suggests that the rate of the wage and its structure has an impact on the economic situation and global demand and promotes the competitiveness of the economy, have an impact on companies and their products. The concept of competitiveness is analysed by the many scientists (Schwab, Porter 2007; Meilienè, Snieška 2010; Dijkstra et al. 2011; Buračas et al. 2012;
Rakauskienė, Tamošiūnienė 2013; Žitkus, Mickevičienè 2013; Camagni, Capello 2014).

One of the ways to understand competitiveness is the fact that it is the ability of certain subject to lead and achieve the better results of activity (Bruneckienè, Kilijonienė 2011). In this case, competitiveness is defined as the set of institutions, policies and factors, which increases the level of country's competitiveness by encouraging the increase of the business activity productivity. Competitiveness is defined in several ways (see Fig. 1)

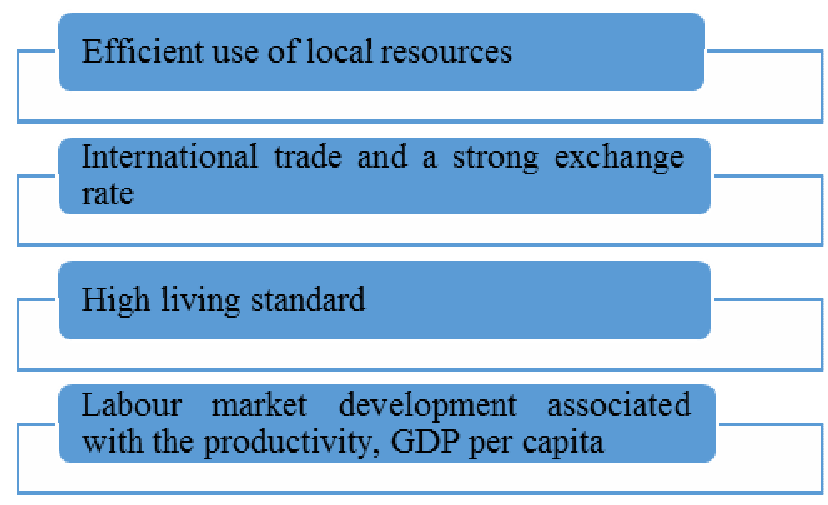

Fig. 1. The definitions of competitiveness (Source: compiled by authors based on Meilienè, Snieška 2010;

Bruneckienè, Kilijonienė 2011; Rakauskienè, Tamošiūnienè 2013)

The concept of competitiveness can be analysed in the narrow (enterprise, micro) level and a broader (national, macro) level (Dijkstra et al. 2011; Žitkus, Mickevičienè 2013).

Company's competitiveness is perceived as its ability to increase market share, while producing and sale the relevant quality products and services that meet market needs. If the company better adapts to the needs of the market, the greater share of the market it will be able to take. The competitiveness in micro (enterprise) level is defined as the competition between similar profiles companies, where is competed for customers and aims to make efficient use of available internal potential.

Regions (countries) competitiveness cannot be directly transferred from the corporate level, because regions are not the sum of the company or a smaller country's version. Country's competitiveness is related to its level of development and economic structure, because it is defined as a set of institutions, policies and factors, which determines the country's competitiveness level (Schwab, Porter 2007). Region competitiveness - the region's ability to create the economic, social, infrastructural and institutional conditions under which companies achieve better activity results and people are more satisfied their needs compared with other 
regions. The country's competitiveness is often defined as the successful country's foreign trade, the country's productivity, the ability to ensure the welfare of its residents (Rakauskienè, Tamošiūnienè 2013). Essential aspects (source) of competitiveness is illustrated in Figure 2.

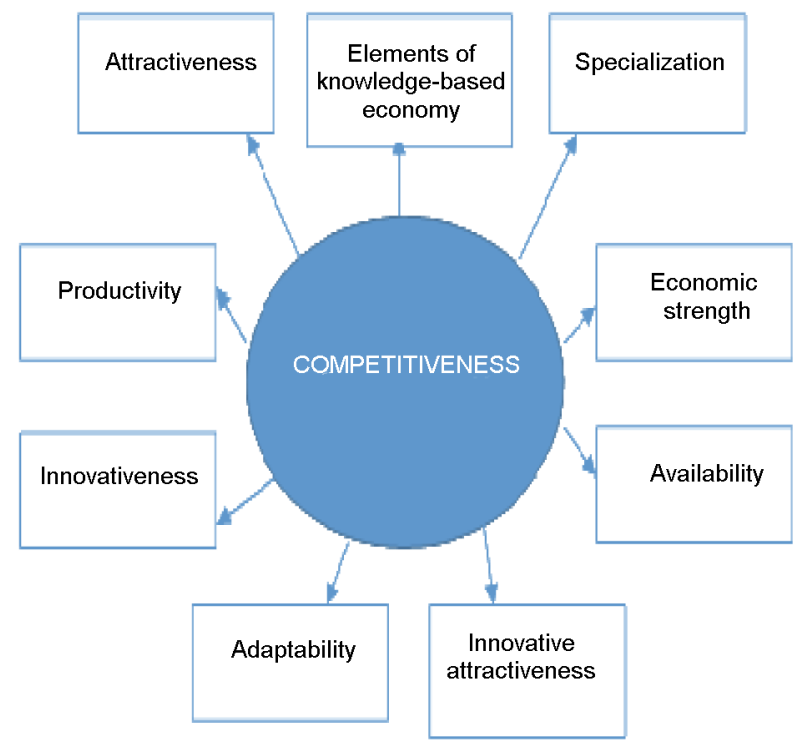

Fig. 2. The sources of competitiveness (Source: compiled by authors based on Žitkus, Mickevičienè 2013)

Figure 2 shows that competitiveness is closely related to productivity, increased availability, adaptability, productivity and elements of knowledgebased economy. The services of professional orientation promotes the lifelong learning, employment, labour force adaptation to market conditions, entrepreneurship (Žitkus, Mickevičienė 2013). Competitiveness capabilities creates preconditions to build a modern, knowledge-based society, to sustainable economic growth, the increase of the country's economic competitiveness and sustainable (smart) growth (Camagni, Capello 2014).

The growth of major values of competitiveness is also highlighted:

- economic globalization as an open to goods, services, capital, people and knowledge economy, which is stimulated by information technologies and the development of transport systems;

- concentration of the population, where is accumulated the potential that creates new requirements, needs and opportunities;

- the growth of economic and social life tempo, when the scientific results are used efficiently.

The assessment of economic competitiveness is determined by applying the relevant aspects and assessing the strategic solutions of economic development according to general criteria. The macroeconomic benefits are a key factor that influence economic competitiveness.

\subsection{Methods for the setting of efficient wage}

Wage level is influenced by the market and institutional factors. Key market factors are workers' professional skills, competence, the level of regional development, social and economic opportunities of countries, living standards. The main institutional factors, that influence wage amount, are work time, used energy, labour content and the value for organization, employee's competence, work quality, supply and demand in the labour market and wage level at analogous organizations.

The employment forms (full-employment, internship), company size, ownership, the size of region and place, capital (Polak 2015) also influence the disparities of wage and income. However, it is necessary to establish an efficient wage, which meet the needs of employees and employer's possibilities.

Scientist (Beck-Krala 2013) suggest, that efficient wage is determined on the base of the following stages:

- monitoring the competitiveness practice and the results of the local market in the area of wage;

- integrating the wage system with other systems and procedures (also personal);

- defining the wage systems and efficiently communicating about their for employees;

- attracting employees to the creation process and to the formation of wage program;

- training managers how to apply the appropriate wage tools;

- systematically verify the efficiency of wage system;

- systematically evaluating employees' work results.

In order to efficient wage determination, appropriate wage-setting methodologies, based on relevant wage theories, are applied. Modern theories are different or have a wider range. In the scientific literature are distinguished three groups of hypotheses (Knapińska 2009; Markowicz 2015):

- related to structural and institutional factors as responsible for the inequalities in the labour market (segmentation theory);

- inequality that has been influenced by the long-lasting adaptation processes in the labour market (human capital theories, the theory of the natural unemployment rate, the labour market search theories); 
- inequality in the labour market is caused by stable wage (efficient wage theory).

Modern economists says, that the labour market activity is described by a neoclassical theory. Perfectly competitive labour market is described by the labour demand and supply curve. Neoclassical theory in perfectly competitiveness market creates precondition for homogeneity of labour resources and wage elasticity, so it is possible to achieve equality between demand and supply. In this case, wage depends on the position of the curve. Each changes of wage also changes the equality. The growth of labour demand and the decline of labour supply leads to the growth of wage and decline of demand and growing of supply reduces wages, so employees are employed with their minimum acceptable wages, which are market rates. According to this theory, the wage level has no effect on labour productivity, but if for the employees will be offered a higher wage than the minimum, then a growing interest in the work will improve labour productivity.

Equality between the demand and supply is also provided by the Leibenstein theory (Matuszewska-Janica, Hozer-Koćmiel 2015). The theory of curve was also developed by Mirrlees (1975), Stiglitz (1981). Labour supply depends on the value of an alternative activities and demand depends on the productivity and value of employed persons. The employer offers such a reward for the work that guaranteed the lowest wages costs, which has one of the efficient work unit. When the efficient wage is paid, the supply exceed demand and the forced unemployment occurs. Equality between demand and supply is expressed as efficiencyquality model (see Fig. 3), which states that if the marginal productivity exceeds the average the employment rate is too low, but in the opposite case equation between supply and demand are possible only through taxes (Stiglitz 1981).

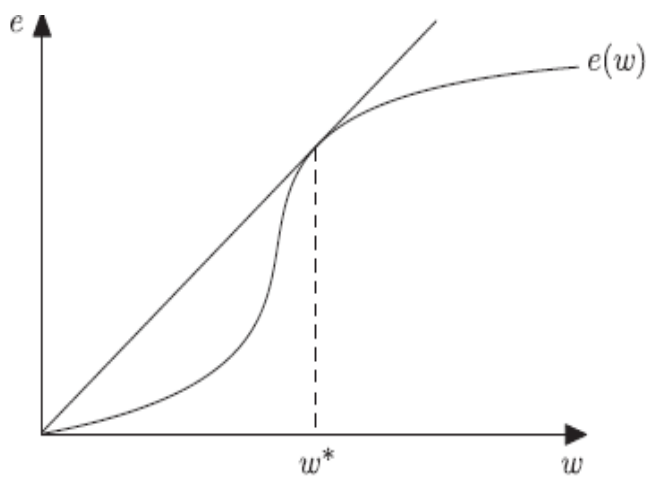

Fig. 3. Efficiency-quality model - equality between wage and productivity (Source: Stiglitz 1981; Stiglitz 1987)
Figure 3 shows the equality between wage and productivity. $\mathrm{e}-$ it is efficiency (productivity), $\mathrm{w}-$ wage. $w^{*}$ indicates efficient wage, where is achieved the equality between efficiency and wage. The wage is marked as an efficient point of intersection where the highest productivity and wage is. Up to that, point cost decreases, over this point - increasing (Stiglitz 1987). Therefore, the employees need to gain only efficient wage. The growth of wage encourages more than proportional growth of productivity. The employer choose to pay the wage, which carries the lowest labour cost per efficiency unit or efficiency labour unit.

This is also confirmed by the efficient wage theory. The roots of the efficient wage theory reach the 50 years of twentieth century. Leibenstein published the theory (1957) and argued that the competitive labour market determines the wage that the employees do not always have something to eat healthily, so the growth of wage should promote their productivity. The higher wages leads to the ability to eat more healthy food and to increase productivity. However, if wages grow unreasonably, labour cost will grow too and they will be higher than productivity so it can cause side effect - forced unemployment.

Summary, at each sector are paid the different wages, which depends on location, industry or company size. The higher wages reduce labour costs and optimal wage in each sector must be different. The technical improvement of each wage level increases productivity, but it cannot only lead to higher unemployment and lower domestic output. Paying higher wages creates preconditions for the productivity increase and so the labour force become more skilled. More skilled labour force increase their productivity and it leads to the better country's economic situation and higher competitiveness.

\section{Dynamics of the productivity and wage}

Following a thorough analysis of the scientific literature in the context of evaluation of interactions between wage and productivity highlighted the need to reveal the dynamics of the abovementioned factors. Assessing the dynamics of the productivity and wage the 2008-2014 years rates were used. This period tends to look, how over the years and under changing circumstances labour productivity was changing as well as on changing wage levels. Figure 4 illustrated the changes of work productivity, which are calculated as a percentage of the previous year. 


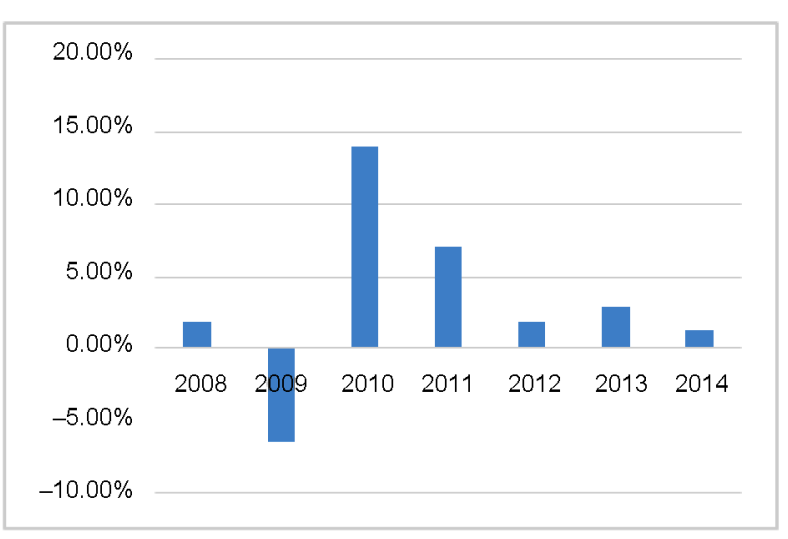

Fig. 4. Labour productivity changes ( $\%$ from previous year) (Source: compiled by authors based on Statistics Lithuania 2015; Eurostat 2015)

Figure 4 shows that in the first years after the 2008 years crisis labour productivity felt rapidly. This was primarily because the companies had no possibilities to recover after the recession and to eliminate the consequences of the crisis. Of course, at that moment it was necessary to reduce wage and it was not possible to use more advanced technologies and appropriate staff motivation decreased. This negatively affected the labour productivity, which compared to past with past year decrease more than 6 percent. However, already in 2010 year is seeing a rapid growth, which is likely consequence of growing employee's motivation to work. This means that the effects of the crisis was slowly eliminated.

The income gained in this period should be also assessed. The study is based on the information about gross wage (in euros) in national economy. The Table 2 shows the data about gross wage for 2008-2014 years period.

Table 2. Gross wage in Lithuania at the 2008-2014 y. y. (Source: compiled by authors based on Statistics Lithuania 2015)

\begin{tabular}{c|c}
\hline Years & Gross wage (EUR) \\
\hline 2008 & 623,2 \\
\hline 2009 & 595,5 \\
\hline 2010 & 575,8 \\
\hline 2011 & 629,9 \\
\hline 2012 & 615,1 \\
\hline 2013 & 646,3 \\
\hline 2014 & 677,4 \\
\hline
\end{tabular}

Table 2 shows that wage changes are closely related to productivity. At analysed period, gross wage decrease is obtained and growth is visible only in 2011 year. It follows that productivity grows faster than wages, so wage is not only factor that determines employee productivity growth. Other productivity raising measures as improved management and work methods, IT implementation in the production process, raise in employee's motivation with non-cash instruments also are possible.

Combining labour productivity and wage, their mutual dynamics is assessed. Average gross monthly wage and annual percentage change of labour productivity is shown in Figure 5.

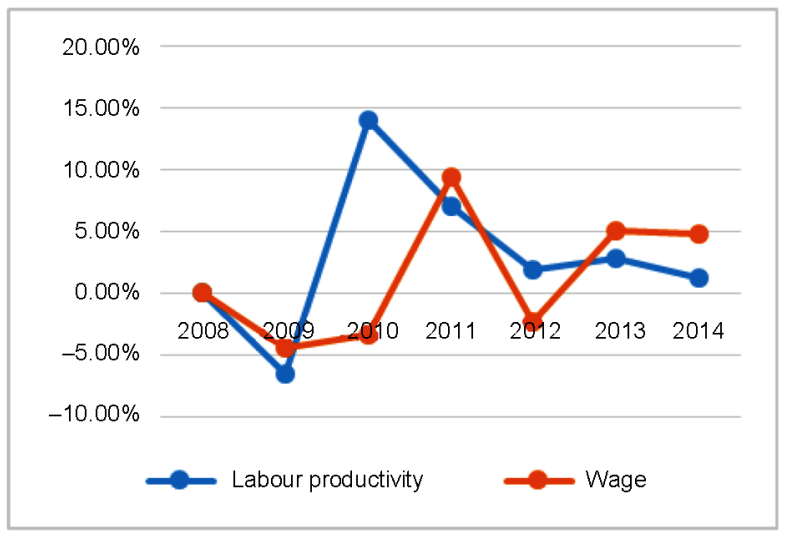

Fig. 5. Labour productivity and wage changes ( $\%$ from previous year) (Source: compiled by authors based on Statistics Lithuania 2015; Eurostat 2015)

The Figure 5 shows that from 2008 untill 2009, 2011 and from 2012 untill 2014 years. Wage grows faster than productivity. The biggest wage "jump" is visible only in 2011 year when, compared to the previous years, gross wages increased by 9,4 percent. Since wages grew faster than labour productivity, it means that wage was increased by the additional funds. However, there is a tendency that from 2009 untill 2012 year labour productivity was higher than wages, so it can be said that productivity was increased by encouraging the use of an active new measures.

In addition, in order to reveal the strength of the interaction between labour productivity and wage was carried out correlation and regression analysis (Oulton, Sebastia-Barriel 2013; Čekanavičius, Murauskas 2014; Dudzevičiūte, Čekanauskas 2014). This analysis was used to find the correlation coefficient, determination coefficient and regression equation. The analysis is based on the 2008-2014 years data. The results of the correlation and regression analysis are presented in the Table 3.

The correlation coefficient indicates the strength of the interaction and the direction of dynamic of the analysed factors (Dudzevičiūte, Čekanauskas 2014). The results of the analysis have 
Table 3. The results of correlation and regression analysis (Source: compiled by authors based on calculations)

\begin{tabular}{l|c}
\hline Correlation coefficient (r) & 0,643 \\
\hline Regression coefficient (R) & 0,413 \\
\hline Regression equation & $\mathrm{Y}=-1,97+3,02 \mathrm{X} 1$ \\
\hline
\end{tabular}

shown that the correlation coefficient is 0,643 , while according to the researchers (Čekanavičius, Murauskas 2014) arguments that if correlation coefficient is between 0,50 and 0,69 it means between the factors exists moderate connection. The regression equation explains 41,3 percent of productivity dynamics. This means that the increase in productivity leads to the growth in wage, so these two factors should be taken into account in determining efficient wage, solving problems of the productivity decline and, of course, trying to reach the country's competitiveness and assessment on a global scale.

In summary, between wage and productivity is quite a strong relationship, which is shown both in graphic way and in the results of the correlation and regression analysis. Among the factors exists a moderate relationship and the regression equation explains about 41 percent of the dynamic of productivity changes. Increasing wages leads to the growth in motivation to work more productively and in that way the problem of declining productivity can be solved, so, the country's competitiveness on a global scale will increase.

\section{Conclusions and suggestions}

- Based on the analysis of theoretical aspects of productivity and wage, it can be argued that the special attention should be given for wage level as a remuneration for use of labour force. After the determination of efficient wage the productivity, employment and GDP will increase and, of course, the economic situation of the country will be improved. Better country's economic situation leads to the country's competitiveness growth, so here are strong relation between competitiveness, wage and productivity level.

- Competitiveness is often described as the efficient use of local resources, high standard of living and the fostering of the labour market and productivity, when the competitiveness is connected with the free movement of goods, services, capital, people and knowledge and the science innovation applying in practice. Competitiveness is also closely related with the growth of labour productivity, which depends on the setting of efficient wage. Efficiency wage theory is based on the features of the wage - productivity curve, where is searching for the point of intersection between productivity and wage, which leads to the country's competitiveness development.

- The results of the labour productivity and wage interactions analysis and its dynamics shows that the labour productivity and wage influence the country's economy. From 2009 till 2012 year labour productivity was higher than wages, so it can be said that productivity was increased by encouraging the use of an active new measures: through the management and work methods improvement, implementation of IT at production process, fostering employees' motivation to work.

- The results of the correlation and regression analysis showed that between the labour productivity and wage exist a medium strong connection, because the correlation coefficient $r$ is equal 0,643 . The regression equation explains 41,3 percent of the productivity dynamics (the regression coefficient is equal 0,413 ). This means that the changes of wage will be reflected also in the dynamic of productivity. Therefore, on the base of the theory of efficient wage it is necessary to establish the level of wages, which would make it possible to achieve the highest possible labour productivity.

- The authors have one main suggestion for the nurturing of the country's competitiveness. Based on the results of analysis and calculations it can be said that the growth in wage leads to the greater employee's productivity and motivation to work. In addition, it leads to the better economic situation and country's competitiveness growth. Therefore, each company determining the employee's wage should found the equality between demand and supply and this point shows the highest productivity with the fixed wage and lowest labour costs. While reaching this point, the country's competitiveness is the highest. The highest productivity and lowest labour costs can be reached also implementing new technologies and innovation in practice. It makes preconditions to create the better quality products and provide timely and qualitative services and it follows that the country's position in the international market will be improved. 


\section{References}

Addison, J. T.; Blackburn, M. L.; Cotti, Ch. D. 2013. Minimum wage increases in a recessionary environment, Labour Economics 23: 30-39. http://dx.doi.org/10.1016/j.labeco.2013.02.004

Appleby, R. C. 2003. Šiuolaikinio verslo organizavimas. Vilnius: Charibdè. 488 p. ISBN 9986-745-63-2.

Beck-Krala, E. 2013. Kształtowanie systemów wynagrodzeń pracowniczych w czasie kryzysu, Organizacja i Kierowanie 4(157): 105-117. ISSN 0137-5466.

Beržinskienè, D.; Raziulytè, S. 2012. Darbo našumo ir darbo užmokesčio tarpusavio priklausomybès vertinimas Lietuvos pavyzdžiu, Ekonomika ir vadyba: aktualijos ir perspektyvos 2(26): 33-41. ISSN 1648-9098.

Bruneckienè, J.; Kilijonienè, A. 2011. Lietuvos regionų konkurencingumo klasterinè analizè, Management Theory and Studies for Rural Business and InFrastructure Development 25(1): 60-69. ISSN 1822-6760.

Buračas, A.; Žvirblis, A.; Jokšienè, I. 2012. Measurement of entrepreneurship macro surrounding advantages: country's economic competitiveness approach, Engineering Economics 23(1): 5-13. http://dx.doi.org/10.5755/j01.ee.23.1.1219

Camagni, R.; Capello, R. 2014. Rationale and design of EU cohesion policies in a period of crisis with special reference to CEECs', GRINCOH Working Paper Series, Policy Paper 1: 1-20.

Čekanavičius, V.; Murauskas, G. 2014. Taikomoji regresine analize socialiniuose tyrimuose. Vilnius: Vilniaus universiteto leidykla. 561 p. ISBN 978609-459-300-0.

Danilevičienė, I.; Kvietkauskienè, A. 2015. The interactions of wage changes and sustainable investment - example of Lithuania, Asian Journal of Business and Management 3(5): 392-401. ISSN 2321-2802.

Dijkstra, L.; Annoni, P.; Kozovska, K. 2011. A new regional competitiveness index: theory, methods and findings, European Union Regional Policy Working Papers 2: 1-28.

Dudzevičiūtè, G.; Čekanauskas, J. 2014. Priežastinio ryšio tarp nedarbo ir emigracijos tyrimas Lietuvoje, Verslas: teorija ir praktika 15(4): 294-301. http://dx.doi.org/10.3846/btp.2014.516

European Commission. 2010. Europe 2020. A strategy for smart, sustainable and inclusive growth. COM 2020. Brussels 3.3.2010. 32 p.

Eurostat. 2015. Real labour productivity per person employed [online], [cited 01 February 2016]. Available from Internet:

http://ec.europa.eu/eurostat/web/productsdatasets/-/tipsna70

Golnau, W. 2012. Teoria płacy efektywnej, Zarzadzanie $i$ Finanse 2(1): 151-159.
Gomez-Salvador, R.; Musso, A.; Stocker, M.; Turunen, J. 2006. Labour productivity developments in the Euro area, Occasional Paper Series 53: 1-35. ISSN 1725-6534.

Jorgenson, D.; Gollop, F. M.; Fraumeni, B. 2014. Productivity and US economic growth. Elsevier. 559 p. ISBN 0-444-70353-5.

Knapińska, M. 2009. Przeplywy pracowników w świetle makro- i mikroekonomicznych teorii rynku pracy. Teoretyczne i praktyczne aspekty funkcjonowania gospodarki. Szczecin: Print Group.

Leibenstein, H. 1957. The Theory of Underemployment in Backward Economies, Journal of Political Economy 65(2): 91-103. http://dx.doi.org/10.1086/257894

Markowicz, I. 2015. Statystyczna analiza przestrzennego zróżnicowania bezrobocia w Polsce, Studia Ekonomiczne 223: 247-256. ISSN 2083-8611.

Matuszewska-Janica, A.; Hozer-Koćmiel, M. 2015. Struktura zatrudnienia oraz wynagrodzenia kobiet i mężczyzn a przedmiotowa struktura gospodarcza $w$ państwach UE. Prace Naukowe Uniwersytetu Ekonomicznego we Wrocławiu 385 Taksonomia 25 Klasyfikacja i analiza danych-teoria i zastosowania: 178-186. ISSN 1899-3192.

Meilienè, E.; Snieška, V. 2010. Lietuvos pramonès konkurencingumo veiksniai eksporto politikos nuostatose, Viešoji politika ir administravimas 31: 119-132. ISSN 2029-2872.

Mirrlees, J.A. 1975. A pure theory of underdeveloped economics using a relationship between consumption and productivity, in L. A. Reynolds (Ed.). $A g-$ riculture in Development Theory. New Haven: Yale University Press.

Oulton, N.; Sebastia-Barriel, M. 2013. Long and shortterm effects of the financial crisis on labour productivity, capital and output, Working Paper 470: 1-55. ISSN 1749-9135.

Polak, E. 2015. Regionalne zróżnicowanie wynagrodzeń w Polsce i tendencje zmian w tym zakresie, Współczesna Gospodarka 6(1): 19-32. ISSN 2082677X.

Rakauskienė, G.; Tamošiūnienè, R. 2013. factors influencing national competitiveness, Business: Theory and Practice 3: 177-187. http://dx.doi.org/10.3846/btp.2013.19

Schwab, K.; Porter, M. E. 2007. The global competitiveness report 2007-2008, World Economic Forum. Geneva, Switzerland. 519 p. ISBN 1403996377.

Stiglitz, J. E. 1981. Alternative theories of wage determination and unemployment: The efficiency wage model. Princeton University, Woodrow Wilson School.

Stiglitz, J. E. 1987. The causes and consequences of the dependence of quality on price, Journal of Economic Literature 25 (1): 1-48. 
Statistics Lithuania. 2015. Wage and labour productivity data [online], [cited 01 February 2016]. Available from Internet: www.stat.gov.lt

Summers, L. H. 1988. Relative wages, efficiency wages, and Keynesian unemployment, National Bureau of Economic Research 2590: 1-16. http://dx.doi.org/10.3386/w2590

Šileika, A.; Tamašauskienè, Z.; Bartalienè, N. 2010. Comparative analysis of wages and labour productivity in Lithuania and other EU-15 countries, Socialiniai tyrimai 3(20): 132-143. ISSN 13923110 .
Vanagas, P. 2009. Darbo organizavimas, normavimas ir atlyginimas už darbq. Kaunas: Technologija. $370 \mathrm{p}$.

Wratny, J. 2013. Problemy regulacji wynagrodzenia za pracę de lege ferenda, Praca $i$ Zabezpieczenie Spoleczne 10: 2-9.

Žaptorius, J. 2005. Darbo rinka: darbo užmokesčio tendenciju barometras, Filosofija, sociologija 4: 5361.

Žitkus, L.; Mickevičienè, M. 2013. Konkurencingumas kaip regiono plètros siekinys, Viešoji politika ir administravimas 12 (3): 430-441. ISSN 16482603. 